\title{
Vancomycin Resistance pattern of Staphylococcus aureus Isolated from Skin and Soft Tissue Infections (SSTI) in Mosul City
}

\author{
Muna M. Isaam \\ Department of Biology / College of Science \\ Mosul University
}

Received

$19 / 11 / 2007$
Accepted

03 / 03 / 2008

Vancomycin لضمن البحث دراسة التأثثر التثيطي للمضاد الحيوي الفانكومايسين والمستخدم في علاج العنقوديات الذهبية المقاومة للمضاد الحيوي الميثئين Methicillin على بعض عزلات العنقوديات الذهبية Staphylococcus aureus المعزولة من الاصابات الجلدية المختلفة والأنسجة الاخوة. أظهرت الننلئج وجود مقاومة لهذا المضاد من قبل بعض العزلات وان التان

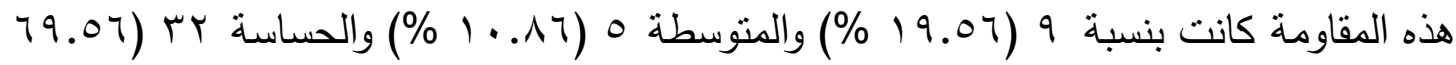
\%). أظهرت الدراسة أيضاً وجود علاقة بين مقاومة المضاد وقدرة العزلات الجرثومية على إنتاج الذيفان المحدث للتقشر Exfoliative toxin والمعزولة من الإصابات الجلدية الحادة لمرضى

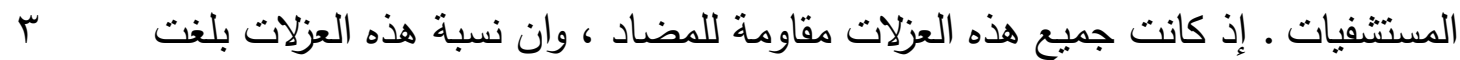

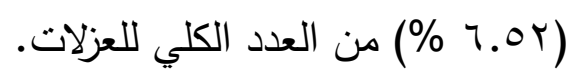

\section{ABSTRACT}

The present study includes the study of the inhibitory effect of vancomycin which has been used as the standard treatment for MRSA Staphylococcus aureus isolated from skin and soft tissue infections (SSTI). Results showed the appearance of resistant isolates 9(19.69\%). Intermediate $5(10.86 \%)$ and susceptible $32(69.56 \%)$. The study also revealed that there was a relationship between antibiotic resistance and exfoliative toxin producing (ETS) isolated from hospitalized patients suffering severe epidermal lesions. The incidence of ETS resistant to vancomycin was $3(6.52 \%)$ of total strains. 


\section{Introduction}

Skin and soft tissue infections were the most common presentations of community - acquired S. aureus infections (1). The growing incidence of these infections that are resistant to antibiotics has important implications in both hospital and community (2). Since 1960s, treatment of these infections was more difficult as $S$. aureus has progressively acquired resistance to various effective antibiotics, including the commonly used penicillin related antibiotics (3).

Worrisome recent examples of drug resistance included vancomycin resistant (VRSA) and community - acquired methicillin resistant $S$. aureus (CA-MRSA). Methicillin - resistant S. aureus (MRSA) are resistant to B-lactam antibiotics "methicillin, oxacillin, nafcillin" and cephalosporin (4-5). Most MRSA are hospital-acquired, although on increasing number are reported to be community acquired. Alimited number of clones of MRSA have spread all over the world. Since community - acquired MRSA can be traced back to some contact with health care, MRSA can still best combatted by control measures in health care institution (6). In this respect the Nether-lands and scandinavian countries have been very successful so far, S. aureus has many virulence factors at its disposal: structural components, enzymes and three types of toxins. (7).

Vancomycin intermediate $S$. aureus (VISA) and vancomycin resistant $S$. aureus (VRSA) are specific types of antibiotic-resistant strains. While most staph are susceptible to this antibiotic, Some have developed resistance. The emergence of VRSA is of great concern to clinicians and public health official as vancomycin is typically drug of least resort intreating St. aureus and several other infection (8). The development of penicillin, methicillin, and vancomycin-resistant strains showed that $S$. aureus has an enormous adaptive. VISA and VRSA can not be successfully treated with vancomycin because these organisms can no longer be killed by vancomycin. Persons that have had several other health problems, previous infections with MRSA, tubes going into their bodies (such as intravenous (IV) catheters), recant hospitalization and recently been given vancomycin and other antibiotics (9).

This work aims to study the frequency of vancomycin resistance of St. aureus isolates obtained from hospitalized patients in Mosul city, and how we can limit the emerging importance of multidrug-resistant St. aureus including the commonly used penicillin-related antibiotics. 


\section{Materials \& Methods :}

\section{Staphylococcus aureus strains :-}

46 Isolates invasive pathogenic Staphylococcal bacteria St. aureus (produce co- agulase, DNsae, yellow pigment, and ferment monnitol). had been taken from Al-Zahrawii hospital in Mosul which was isolated from patients suffering from skin and soft tissue infections (SSTI). From previous study (10) some of these strains which isolated from severe skin lesions are producing exfoliatve toxin (ETS).

\section{Antibiotic Susceptibility Testing :-}

Vancomycin intermediate Staphylococcus aureus (VISA) and vancomycin resistant Staphylococcus aureus (VRSA) are diagnosed by routine laboratory susceptibility testing according to modified Kirby Bauer method $(11,12)$ in which the inoculum from primary cultures of each isolated strain were prepared by touching with a loop the tops of each of (3-5) isolated colonies of similar appearancy transferred to nutrient broth and incubated at $\left(37{ }^{\circ} \mathrm{C}\right)$ for $18-24 \mathrm{hr}$. the growth was suspended in saline and compared with a tube of turbidity standard of $10^{8}$ cell/ml (12). The density of the tested suspension was adjusted by adding more bacteria or mor sterile saline. The plates of Muller-Hinton agar were inoculated by dipping asterile swab in the above prepared inoculum, excess inoculum was removed by pressing and rotating the swab firmly against the side of the tube above level of the liquid and then swab was streaked all over the surface of the medium three times and rotating the plates through on angle 60 after each application. Finally the swab was passed round the edge of agar surface and the inoculum was left to dry for a few minutes at room temperature with a lid closed. Later vancomycin disc $(30 \mu \mathrm{g})$ [Bioanalyse] was placed on the center of inoculated plate, and plates were incubated at $37{ }^{\circ} \mathrm{C}$ for $18-24 \mathrm{hr}$. The diameter of each zone of inhibition (including the diameter of disc) were measured, recorded and compared with standard zones of inhibition for this antibiotic (13).

\section{Results \& Discussion :}

This study demonstrates for the first time in the epidemiology of VRSA and VISA in hospitalized patients in Mosul city with complicated skin and soft tissue infections (SSTI) (Table 1). Although vancomycin has been the "gold standard" for invasive, most CA-MRSA are localized SSTI that do hospitalization or vancomycin therapy (14). Researchers belive that intermediate resistance develops from pre-existing strains of MRSA in the presence of vancomycin, VISA were identified American starting in 1997. As of 2003, eight cases of VISA had been confirmed in this country (15). It should be emphasized that the VISA isolates studied 
to date have remained susceptible to multiple antimicrobials - including sulfonamids (16). Among the strains isolated 32 (69.56\%) are sensitive to vancomycin antibiotic as shown in (Fig 1), which agreed with (17-19) who indicated that target therapy according highly resistant MRSA isolates and serious infections usually require IV vancomycin therapy, oral vancomycin is poorly absorbed.

Table 1: Interpretation of Inhibition Zones for Bauer-Kirby Antibiotic Susceptibility Testing

\begin{tabular}{|c|c|c|}
\hline Inhibition Zone & Diameter $(\mathrm{mm})$ & No. of strains \\
\hline Susceptible (S) & 12 ormore & $32(69.56 \%)$ \\
\hline Intermediate (I) & $10-11$ & $5(10.86 \%)$ \\
\hline Resistant (R) & $0-9$ & $9(19.56 \%)$ \\
\hline
\end{tabular}

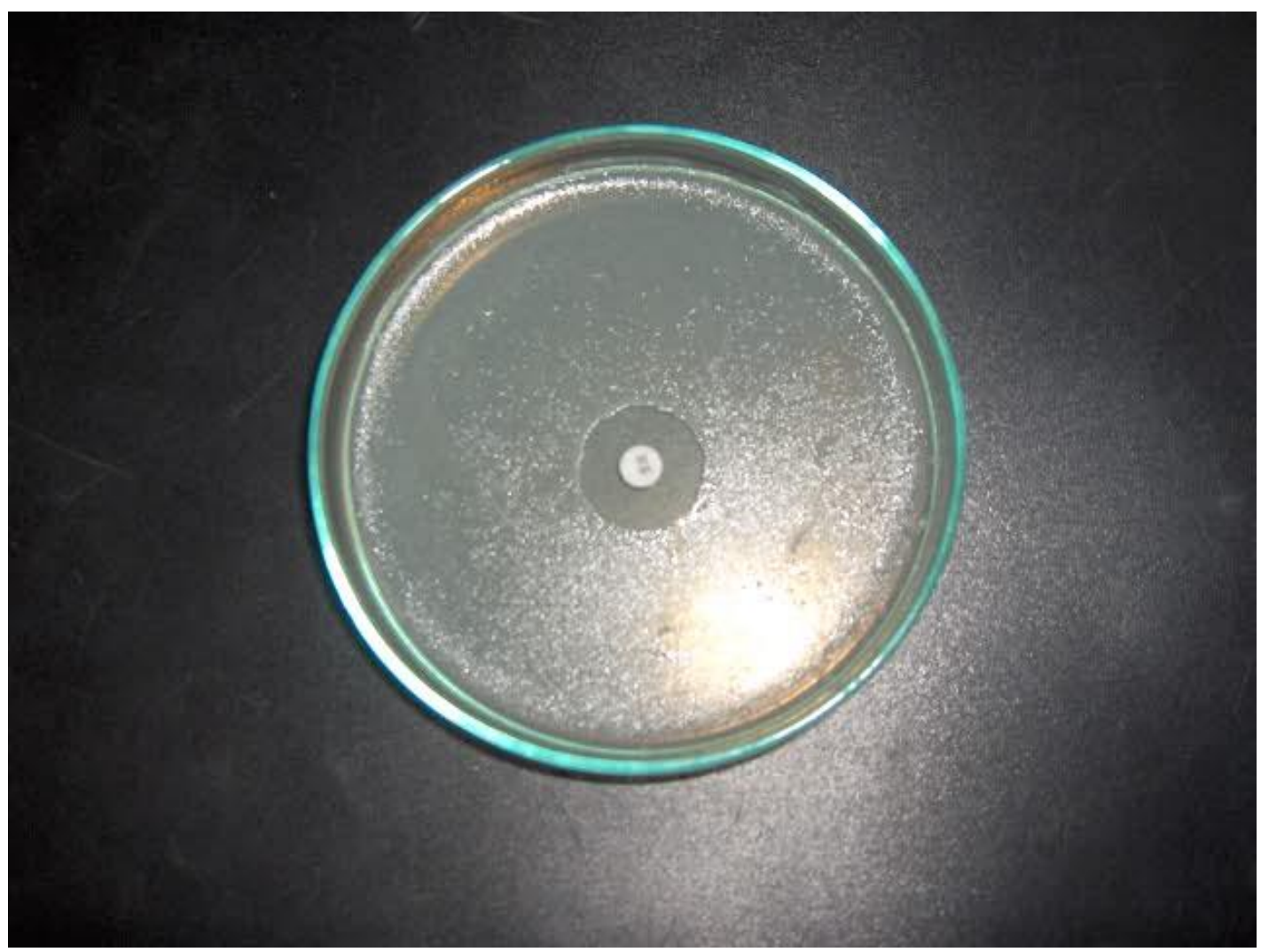

Fig 1 : Vancomycin Sensitive Staphylococcus aureus

Though the emergence of VISA (Fig 2) and VRSA (Fig 3) may have caught physicians and patients unawares, vancomycin-resistant $S$. aureus (VRSA) minimum inhibitory concentration (MIC) $\geq 32 \mu \mathrm{g} / \mathrm{ml}$, was first recognized in 2002. There have now three documented clinical isolate of VRSA from patient, in united states. To once again, it is 


\section{Muna M. Isaam}

important to note that all VRSA infections have been susceptible to other antibiotics like linezolid and Daptomycin (which represent completely novel classes of antibiotics) (20,21).

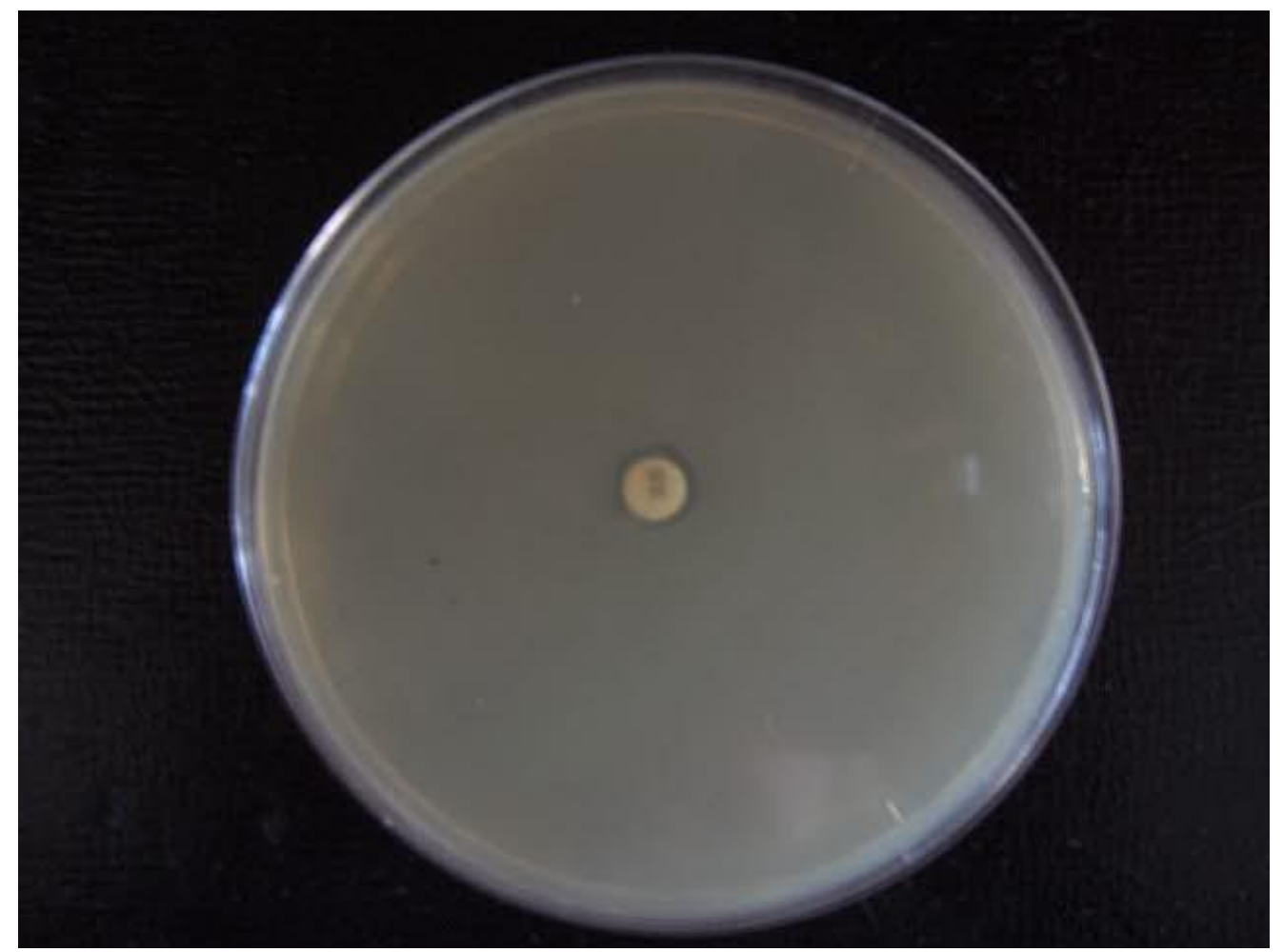

Fig 2 : Vancomycin Intermediate Sensitivtiy Staphylococcus aureus

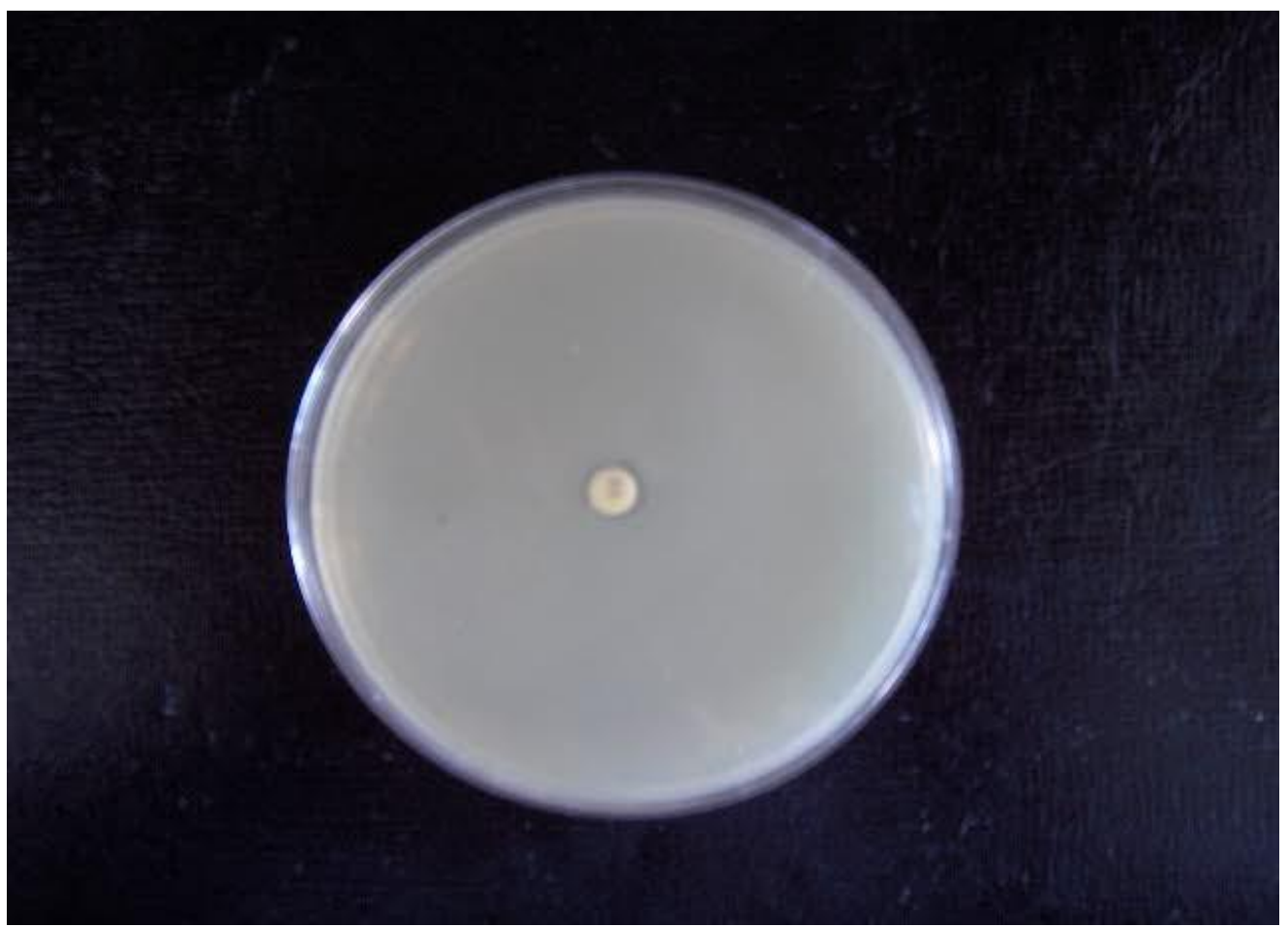

Fig 3 : Vancomycin Resistant Staphylococcus aureus 
Finally the study also was performed to understand an association between the vancomycin resistance of $S$. aureus $3(6.52 \%)$ and production of exfoliative toxin (Fig 4). This finding were supported by those $(22,23)$ Who stated that two strains of CA-MRSA in Switzerland carried the eta genes encoding exfoliative toxin out of 10 strains studied ((All carried accessory gene regulator (agr) allele group (alleles 1-4) and Staphylococcal cassette chromosome me (Sccmec) allele (I-IV)), and had a pulsed - field gel electrophoresis (PFGE) profile related to that of etapositive CA-MRSA strain from Japan.

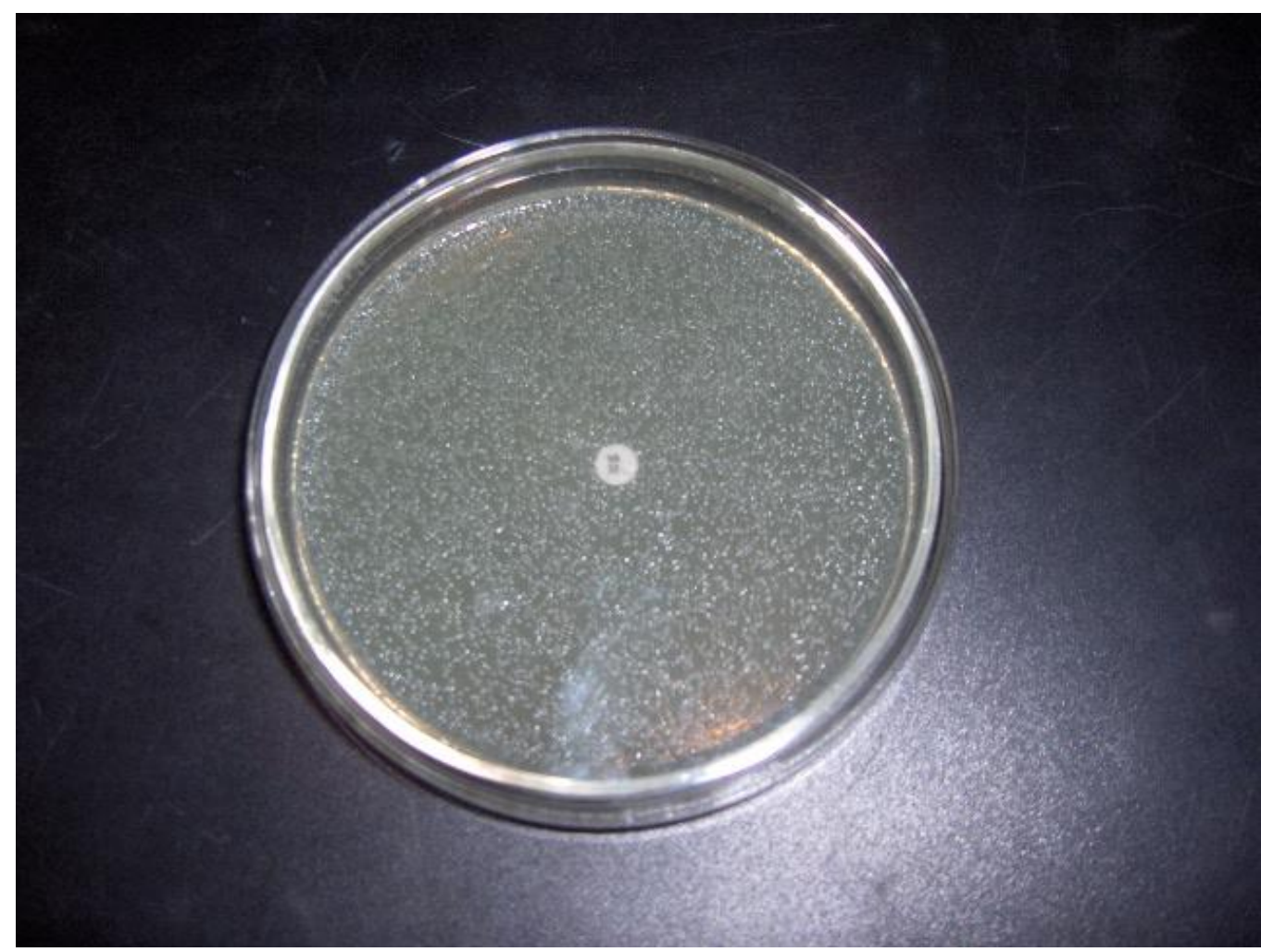

Fig 4 : Vancomycin Resistant Staphylococcus aureus producing exofoliative toxin

The public health response to identification of this VRSA infection is on going. Use of proper infection control and appropriate antimicrobial agent management can help limit the emergence and spread of antimicrobial resistant microorganisms, including VRSA. Control Disease Center (CDC) recommends contact precautions when caring for patients with these infections, including: 1) placing the patient in a private room; 2) wearing gloves and a gown during patient contact; 3) washing hands after contact with the patient, infectious body tissues, or fluids, and 4) limiting the use of patient-care items to individual patients. In addition, the number of persons caring for a patient with VRSA or vancomycin intermediate $S$. aureus should be minimized (e.g) by assigning dedicated staff to care for the patients (24). 


\section{References :}

1. Eady E. A., Cove J. H. Current Opinion in Infectious Diseases. 16(2): 103-241 (2003) Apr.

2. Paul krogstad M. D. Pediatric update 12:2 (2005).

3. Lowy FD. N Engl J Med 339: 520-32 (1998).

4. Naimi TS., LeDell KH., Como-Sabetti K. et al. JAMA, 290: 2976-84 (2003).

5. Said-Salim B., Mathema B., Kreiswirth BM. Infect control Hosp Epidermiol (6): 451-5 (2003).

6. Naimi T. S., K. H., LeDell D. J., Boxrud A. V., Groom C. D., Steward S. K., Johnson J. M., Besser C. O., Boyle R. N., Danila J. E., Cheek M. T., Osterholm K. A., Moore and K. E. Smith. 19961998. Clin. Infect. Dis 33: 990-996 (2001).

7. Van den Broek, PJ. Neder lands Tijdschrift voor Genee skunde. 147(22): 1045-8, May 31(2003).

8. Smith T. L., Pearson M. L., Cruzc, Lancaster M. V., Robinson. Dunn B., Tenover F. C., Zervos M. J., White E, Jarris W. R. N Engl J Med. 430 (7): 493-501 (1999).

9. Hageman J. C., Pegues D. A. Jepsene, Bell R. L., Guinan M., Ward K. W., Cohen M. D., Hindler J. A., Tenover F. C., Allister S. K., Kellum M. E., Fridkin S. K. Emerg Infect Dis 7 (6): 1023-5 (2001).

10. Sarab D., Alshamaa, Muna M. I., Saam and Reem Z., Shaker. J. Edu. Sci. Vol. (19) No. (3) 51-58 (2007).

11. A. ch. Al-Doody, phD. Thesis, College of Science, university of Mosul. (1998).

12. J. B. Harbone "Phytochemical Method", A Guide to Moder Technique of plant analysis $1^{\text {st }}$ es. (1973).

13. Ronald M. Atlas, principles of Microbiology, $1^{\text {st }}$ Edition, MosbyYear Book, Inc. Printed in USA (1995).

14. Markowitz N., Quinn E. L., Saravd at ZLD. Am. J. Med 117: 390-8, (1992).

15. Scott K., Fridkin, 32 Health care Epidemiology 108,110-12 (2001).

16. John H. Powers, Clinical Microbiology and Infeetion $10: 24$ (2004).

17. Lacy M. K., Tessier P. R., Nicolau D. P., Nightingale C. H., Quintiliani R. International Journal of Antimicrobial Agents. 15 (1): 25-30, Jun (2000). 
18. Loeb M., Main C., Walker-Dilks C., Eady A. Cochrane Database of Systematic Reviews. (4): 3340 (2003).

19. Koning S., A. Van Belkum S., Snijders W., Van Leeuwen H., Verbrugh J., Nouwen M., Op't veld L. W., Van Suijlekom-smit J. C. Vander wooden and C. verduin. J. Clin. Microbiol. 41: 3017-3021 (2003).

20. Changs Sievrt D. M., Hageman J. C., Boulton M. L., Tenover F. C., Downes F. P., Shah S., Rudrik J. T., Pupp G. R., Brown W. J., Cardo D., Fridkin S. K. N Engl. J. Med. 348(14): 1342-7 (2003).

21. Brief Report: New York, MMWR 53(15); 322-323 (2004).

22. Nadia Liassine, Raymond Auckenthaler, Marie-Christine Descombes-Michele Bes, Francois Vandene sch, and Jerome Etienne. Journal of clinical microbiology, Feb p825-828 (2004).

23. Yamaguchi T., Y. Yokota, J. Teajima, T. Hayashi, M. Aepfelbacher, M. Ohara, H. Komatsuzawa, H. Watanabe and M. Sugai. J. Infect. Dis. 185: 1511-1516 (2002).

24. CDC. MMWR 51 (6) (2002). 